\title{
Urine immune profiling by measurement of multiple cytokine/chemokine mRNA levels in renal allograft dysfunction
}

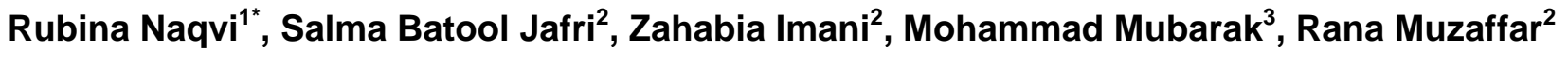 \\ ${ }^{1}$ Department of Nephrology, Sindh Institute of Urology and Transplantation (SIUT), Karachi, Pakistan; ${ }^{*}$ Corresponding Author: \\ rubinanaqvi@gmail.com \\ ${ }^{2}$ Department of Molecular Biology, Sindh Institute of Urology and Transplantation (SIUT), Karachi, Pakistan; \\ ${ }^{3}$ Department of Pathology, Sindh Institute of Urology and Transplantation (SIUT), Karachi, Pakistan.
}

Received 3 August 2011; revised 18 October 2011; accepted 10 November 2011.

\section{ABSTRACT}

Background: An accurate diagnosis of cause of acute renal graft dysfunction is crucial for the optimal management of transplant recipients. Currently available tests are either insensitive or nonspecific, or are invasive, such as allograft biopsy. During last decade, attempts have been made in search of non invasive markers for the evaluation of cause of graft dysfunction. We studied a set of genes expressed on cytotoxic $T$ Lymphocytes and those related to functioning of regulatory or helper T cells. Methods: We obtained 108 urine samples from 108 renal allograft recipients at the time of graft biopsy done for the evaluation of cause of graft dysfunction. RNA was extracted from urinary cells and messenger RNA (mRNA) encoding perforin, granzyme B (GB), FoxP3, CD $3 \in$, CXCR3, TGF- $\beta$, CTLA4, PI-9, IL-10, TNF $\alpha$, T-bet and 18SrRNA measured with the use of quantitative real time polymerase chain reaction (RT-PCR). The levels of expression of genes were correlated with the biopsy findings and the results compared among different groups. Renal allograft biopsies at this institution are performed when there is unexplained rise in serum creatinine of $>20 \%$ from the baseline value and reported according to Banff classification. SPSS v10.0 used for analysis.Results: The mRNA copy numbers of GB, Perforin, FoxP3, CD3, CXCR3, TGF- $\beta$, CTL A4, PI9, IL-10, TNF $\alpha$, and T-bet were log transformed and mean $( \pm$ SD) levels studied. The expression of all studied genes were compared between 'nonspecific biopsy findings' and other specific diagnoses. GB, Perforin, FoxP3, TGF- $\beta$, CD3 $\epsilon$, CTLA4 CXCR3 and T-bet were higher in acute cellular rejection (ACR), whereas, TGF- $\beta$ was also found higher in infection, and PI-9 in chronic allograft nephropathy (CAN) and borderline rejection group. Conclusion: Measurement of mRNA levels for genes like GB, Perforin, FoxP3, TGF- $\beta$, CD3 $\in$, CTLA4, CXCR3 and T-bet in urine samples offers a non invasive means of diagnosing cause of graft dysfunction.

Keywords: Renal Allograft Dysfunction; Rejection; Cytokines; Chemokines

\section{INTRODUCTION}

Acute graft dysfunction remains a major impediment in the successful long-term graft and patient survival in the setting of renal transplantation. Although graft biopsy is still considered the 'gold standard' in the diagnosis of graft dysfunction, it has its limitations. Associated risks like procedure related complications could restrict its routine application in a live related donor transplant program. Therefore, the development of sensitive and specific non-invasive diagnostic tools has been a major area of interest in the field of transplantation [1]. Enhanced mRNA expression of several cytokine and chemokine genes in urinary cells is shown to be associated with acute graft rejection [2-14]. Reverse transcriptasereal time PCR (RT-real time PCR) permits detection and accurate quantitation of high and low abundant mRNA [8]. Expression of cytotoxic $\mathrm{T}$ lymphocyte activation markers including GB, Perforin, integrins such as CD 103, key chemokine inducible protein of $10 \mathrm{kD}$ (IP-10) and its receptor CXCR3 have been shown to be associated with allograft rejection [15-17]. PI-9, an endogenous blocker of GB/Perforin pathway is also implicated in the rejection pathway.[18] Several studies have also highlighted the role of specialized subgroup of $\mathrm{CD} 4^{+}, \mathrm{CD} 25^{+} \mathrm{T}$ lymphocytes 
(Treg cells) and X-linked forkhead/ winged helix transcription factor, Fox P3 [13,19-21]. IL-10, required for the generation of, and suppressor function of Tregs, tumor necrosis factor- $\alpha$ (TNF- $\alpha$ ), known to play an essential role in mediating inflammatory process, and profibrotic cytokine, TGF- $\beta$, are also reported to be involved in graft dysfunction [13,22-26]. Development of CD4 effector $\mathrm{T}$ cells into $\mathrm{T}$ helper $1\left(\mathrm{~T}_{\mathrm{H}} 1\right)$ is regulated by T-bet (T-box expressed in T cells; also known as Tbx-21) which positively regulates its own expression [27-30]. CTLA4 is an important T cell downregulatory molecule that is required for induction of peripheral tolerance in a number of models. It is primarily expressed as an intracellular molecule that cycles to the cell surface where it can then interact with B7 counter-ligands (CD 80 and CD 86) on antigen presenting cells [31]. CTLA 4 expression is up-regulated by $\mathrm{T}$ cell activation, which normally requires signals through both the TCR and the CD 28 co-stimulatory pathways [32]. The availability of sensitive and specific non-invasive tests for diagnosing the causes of graft dysfunction remains the ultimate need of transplant physicians, especially in the setting of live related transplantation. In the present study, we set out to determine the utility of urinary cytokine/chemokine mRNA levels as a noninvasive diagnostic tool in our transplant recipients, where organ source is from live related donors.

\section{MATERIAL AND METHODS}

\subsection{Study Structure}

The study comprised of 108 urine samples from 108 patients who received living related donor kidneys and underwent renal allograft biopsy for determining the causes of graft dysfunction $(>20 \%$ rise in serum createnine from base line). Biopsies were reported and graded according to the Banff 97 classification [33]. All patients reported as ACR were given pulse steroids as anti rejection therapy, whereas, antithymocyte globulin (ATG) was the drug used in cases of vascular rejection and for steroid resistant ACR. Urine samples were collected just before the biopsy procedure on the day the biopsy was performed. The Ethical Review Committee at SIUT approved the study. Written informed consent was obtained from all the participants in the study.

\subsection{Extraction of Total RNA from Urinary Cells and CDNA Synthesis}

The cell pellets were obtained by centrifugation and RNA was extracted and reverse transcribed according to standard protocols. Briefly, urine specimens were centrifuged at $3000 \mathrm{rpm}$ for $30 \mathrm{~min}$ at $4^{\circ} \mathrm{C}$ and washed with chilled PBS ( $\mathrm{pH}$ 7.4). Pellets were re-suspended in RNA later (QIAGEN, GmbH, Germany), followed by storage at $-80^{\circ} \mathrm{C}$ before RNA extraction. Total RNA was extracted using RNeasy Mini Kit (Qiagen, GmbH, Germany) along with QIAshredder Spin Columns (Qiagen, $\mathrm{GmbH}$, Germany). RNA was eluted in $60 \mu \mathrm{l}$ RNase-free water, its concentration and purity determined by OD260/ 280 readings. Between $100 \mathrm{ng}$ and $500 \mathrm{ng}$ of RNA was reverse-transcribed in a final reaction volume of $100 \mu \mathrm{l}$ using cDNA reverse transcription reagents (Applied Biosystems Inc., Foster City, CA, USA). All urinary samples yielded satisfactory quality and amount of RNA for PCR amplification.

\section{3. "Pre-Amplification" Polymerase Chain Reaction (Pre-Amp PCR)}

Multi-plex Pre-Amp PCRs were performed for $11 \mathrm{cy}-$ tokine molecules (FoxP3, CD3 $\varepsilon$, GB, TGF- $\beta 1$, IL-10, PI-9, TNF- $\alpha$, Perforin, CXCR 3, CTLA 4, T-bet)) and 18S rRNA (housekeeping gene) in $30 \mu \mathrm{l}$ using $3 \mu \mathrm{l}$ of cDNA. The amplified products were stored at $-20^{\circ} \mathrm{C}$ until real-time, quantitative PCR was performed. The sequences of primers and probes used in this study are listed in Table 1.

\subsection{Quantitative Real-Time PCR}

In-house $18 \mathrm{~S}$ rRNA standards were used to generate a standard curve for measuring mRNA levels. Briefly, 18S rRNA was reverse transcribed and amplified. The presence of a single PCR product was verified on a 3\% agarose gel. The amplified product was purified using Wizard SV Gel and PCR Clean-up kit (Promega Corp., Madison, WI, USA), quantified by spectrophotometry, and copy numbers calculated.

A series of 10-fold dilutions ranging from $2.5 \times 10^{6}$ to $2.55 \times 10^{2}$ copies were used as standards in duplicates with every run on ABI Prism SDS 7000 (ABI, Foster City, CA, USA). PCR for each of the 11 cytokine gene mRNAs and 18S rRNA was carried out in duplicates. Every real time PCR run had its own $18 \mathrm{~S}$ rRNA standard curve to allow relative quantification of the cytokine gene expressions.

\subsection{Statistical Analysis of Data}

Urinary cytokine mRNA copy numbers were log-transformed before applying the Mann-Whitney test for non-parametric data using SPSS v10.0 for Windows. P-values $<0.05$ were considered statistically significant. Receiver-operating-characteristic (ROC) curve analysis of normalized mRNA levels of all studied genes was carried out to determine the cutoff points that yielded the highest sensitivity and specificity in diagnosis of acute cellular rejection (ACR). 
Table 1. Primer and probe sequences of target genes $[16,18,19]$.

\begin{tabular}{|c|c|c|c|c|}
\hline Gene & Accession no. & & Sequence & location \\
\hline GB & BJ04071 & $\begin{array}{l}\text { Sense } \\
\text { Antisense } \\
\text { Probe }\end{array}$ & $\begin{array}{l}\text { 5'-GCGAATCTGACTTACGCCATTATT-3' } \\
\text { 5'-CAAGAGGGCCTCCAGAGTCC-3' } \\
\text { 5'-CCCACGCACAACTCAATGGTACTGTCG-3' }\end{array}$ & $\begin{array}{l}(534-557) \\
(638-619) \\
(559-585)\end{array}$ \\
\hline Perforin & M28393 & $\begin{array}{l}\text { Sense } \\
\text { Antisense } \\
\text { Probe }\end{array}$ & $\begin{array}{l}\text { 5'-GGACCAGTACAGCTTCAGCACTG-3' } \\
\text { 5'-AGTCAGGGTGCAGCGGG-3' } \\
\text { 5'-TGCCGCTTCTACAGTTTCCATGTGGTACAC-3' }\end{array}$ & $\begin{array}{l}(492-514) \\
(577-561) \\
(526-555)\end{array}$ \\
\hline FoxP3 & NM014009 & $\begin{array}{l}\text { Sense } \\
\text { Antisense } \\
\text { Probe }\end{array}$ & $\begin{array}{l}\text { 5'-GAGAAGCTGAGTGCCATGCA-3' } \\
\text { 5'-GGAGCCCTTGTCGGATGAT-3' } \\
\text { 5'-TGCCATTTTCCCAGCCAGGTGG-3' }\end{array}$ & $\begin{array}{c}(939-959) \\
(1025-1007) \\
(962-984)\end{array}$ \\
\hline $\mathrm{CD} 3 \in$ & NM000733 & $\begin{array}{l}\text { Sense } \\
\text { Antisense } \\
\text { Probe }\end{array}$ & $\begin{array}{l}\text { 5'AAGAAATGGGTGGTATTACACAGACA-3' } \\
\text { 5'-TGCCATAGTATTTCAGATCCAGGAT-3' } \\
\text { 5'-CCATCTCTGGAACCACAGTAATATTGACATGCC-3' }\end{array}$ & $\begin{array}{l}(131-156) \\
(233-209) \\
(170-202)\end{array}$ \\
\hline PI9 & NM004155 & $\begin{array}{l}\text { Sense } \\
\text { Antisense } \\
\text { Probe }\end{array}$ & $\begin{array}{l}\text { 5'-TCAACACCTGGGTCTCAAAAAA-3' } \\
\text { 5'-CAGCCTGGTTTCTGCATCAA-3' } \\
\text { 5'-AGCTACCCGGCAACAACTCTTCAATTTTACCT-3' }\end{array}$ & $\begin{array}{l}(508-529) \\
(590-571) \\
(536-567)\end{array}$ \\
\hline CXCR3 & NM00154 & $\begin{array}{l}\text { Sense } \\
\text { Antisense } \\
\text { Probe }\end{array}$ & $\begin{array}{l}\text { 5'-ACCCAGCAGCCAGAGCAC-3', } \\
\text { 5'-CAACCTCGGCGTCATTTAGC-3', } \\
\text { 5'-CTTGGTGGTCACTCACCTCAAGGACCAT-3' }\end{array}$ & $\begin{array}{c}(41-58) \\
(117-98) \\
(69-96)\end{array}$ \\
\hline IL10 & XM001409 & $\begin{array}{l}\text { Sense } \\
\text { Antisense } \\
\text { Probe }\end{array}$ & $\begin{array}{l}\text { 5'-AGGCTACGGCGCTGTCAT-3' } \\
\text { 5'-GGCATTCTTCACCTGCTCCA-3' } \\
\text { 5'-CTTCCCTGTGAAAACAAGAGCAAGGCC-3' }\end{array}$ & $\begin{array}{l}(394-411) \\
(465-446) \\
(418-444)\end{array}$ \\
\hline TGF $\beta$ & NM000660 & $\begin{array}{l}\text { Sense } \\
\text { Antisense } \\
\text { Probe }\end{array}$ & $\begin{array}{l}\text { 5'-CCCTGCCCCTACATTTGGAG-3', } \\
\text { 5'-CCGGGTTATGCTGGTTGTACA-3' } \\
\text { 5'-CACGCAGTACAGCAAGGTCCTGGCC-3' }\end{array}$ & $\begin{array}{l}(1821-1831) \\
(1884-1864) \\
(1838-1862)\end{array}$ \\
\hline $\mathrm{TNF} \alpha$ & XM165823 & $\begin{array}{l}\text { Sense } \\
\text { Antisense } \\
\text { Probe }\end{array}$ & $\begin{array}{l}\text { 5'-CCCAGGCAGTCAGATCATCTTC-3' } \\
\text { 5'-AGCTGCCCCTCAGCTTGA-3' } \\
\text { 5'-CAAGCCTGTAGCCCATGTTGTAGCAAACC-3' }\end{array}$ & $\begin{array}{l}(302-323) \\
(386-368) \\
(339-367)\end{array}$ \\
\hline CTLA4* & ВC074893 & $\begin{array}{l}\text { Sense } \\
\text { Antisense } \\
\text { Probe }\end{array}$ & $\begin{array}{l}\text { 5'-CGCCATACTACCTGGGCATAG-3' } \\
\text { 5'-GATCCAGAGGAGGAAGTCAGAATC-3' } \\
\text { 5'-ACCCAGATTTATGTAATTGATCCAGAACCGTGC-3' }\end{array}$ & $\begin{array}{l}(441-461) \\
(579-556) \\
(470-502)\end{array}$ \\
\hline Tbet** & ВC039739 & $\begin{array}{l}\text { Sense } \\
\text { Antisense } \\
\text { Probe }\end{array}$ & $\begin{array}{l}\text { 5'-GCCTACCAGAATGCCGAGATTA-3' } \\
\text { 5'-TCAAAGTTCTCCCGGAATCCT-3' } \\
\text { 5'-TCAGCTGAAAATTGATAATAACCCCTTTGCCA-3' }\end{array}$ & $\begin{array}{r}(1086-1107) \\
(1162-1141) \\
(1109-1140\end{array}$ \\
\hline 18SrRNA & K03432 & $\begin{array}{l}\text { Sense } \\
\text { Antisense } \\
\text { Probe }\end{array}$ & $\begin{array}{l}\text { 5'-GCCCGAAGCGTTTACTTTGA-3' } \\
\text { 5'-TCCATTATTCCTAGCTGCGGTATC-3' } \\
\text { 5'-AAAGCAGGCCCGAGCCGCC-3' }\end{array}$ & $\begin{array}{c}(929-948) \\
(1009-985) \\
(965-983)\end{array}$ \\
\hline
\end{tabular}

***_-not published yet, designed with help of Dr. R. Ding while working at Cornell Molecular Lab. Permission granted for use of all primers and probes sequences from Dr. Suthanthiran

\section{RESULTS}

The 108 urine samples were collected from 108 patients at the time of graft dysfunction, defined as $\geq 20 \%$ rise in serum creatinine from the baseline value, on the same day that the graft biopsy was performed. The urinary samples were analyzed for gene expression and correlated with biopsy findings. The relevant demographic, clinical and laboratory characteristics of patients included in the study are summarized in Table 2.

\subsection{Cytokine/Chemokine mRNA Levels in Urinary Cells}

The levels of mRNA and 18SrRNA were log trans- formed for analysis. Since minimum variability $(9.8 \pm$ 0.20 ) was seen for $18 \mathrm{~S}$ rRNA copy numbers, normalization of mRNA levels was not carried out. The levels of mRNA in ACR (IA,IB), AVR (IIA,IIB,III), borderline rejection, CAN, and infection diagnoses were compared with "mild nonspecific" biopsy findings Figure 1 and

\section{Table 3.}

AVR: GB, perforin, FoxP3, TGF- $\beta$, CTLA4 and CXC R3 mRNA levels also showed significant increase in expression, whereas, PI-9, TNF- $\alpha$, IL-10 and T-bet levels showed no significant increase in copy numbers.

Borderline Rejection: No significant increase in expression of studied genes was observed in this group.

Chronic allograft nephropathy (CAN): Highly significant 
Table 2. Patient Characteristics in different groups.

\begin{tabular}{|c|c|c|c|c|c|c|}
\hline & $\begin{array}{c}\operatorname{ACR}(\mathrm{IA}, \mathrm{IB}) \\
(\mathrm{n}=40)\end{array}$ & $\begin{array}{c}\text { Infection } \\
(\mathrm{n}=17)\end{array}$ & $\begin{array}{c}\text { CAN } \\
(\mathrm{n}=17)\end{array}$ & $\begin{array}{c}\text { AVR (IIA, } \\
\text { IIB,III) }(\mathrm{n}=7)\end{array}$ & $\begin{array}{c}\text { Border line } \\
\text { Rejection }(n=5)\end{array}$ & $\begin{array}{l}\text { Normal (Mild nonspe- } \\
\text { cific changes) }(\mathrm{n}=22)\end{array}$ \\
\hline $\begin{array}{l}\text { Recipient Age in years } \\
(\text { mean } \pm \text { SD) }\end{array}$ & $27 \pm 8.2$ & $29 \pm 8$ & $22 \pm 8$ & $23 \pm 7$ & $28 \pm 8$ & $26 \pm 7$ \\
\hline Recipient Sex (M:F) & $35: 5$ & $14: 3$ & $13: 4$ & $7: 0$ & $4: 1$ & $22: 0$ \\
\hline $\begin{array}{l}\text { Duration on Dialysis } \\
\text { in months (mean } \pm \mathrm{SD})\end{array}$ & $7.5 \pm 15$ & $9.2 \pm 22$ & $10.8 \pm 14.7$ & $8.7 \pm 12.3$ & $6 \pm 6.75$ & $6 \pm 7.3$ \\
\hline $\begin{array}{l}\text { Donor Age in years } \\
(\text { mean } \pm \text { SD })\end{array}$ & $34 \pm 9.8$ & $36 \pm 8$ & $36 \pm 7$ & $42 \pm 9$ & $41 \pm 11$ & $33 \pm 9$ \\
\hline Donor Sex (M:F) & $13: 27$ & $8: 9$ & $4: 13$ & $2: 5$ & $2: 3$ & 10:12 \\
\hline \multicolumn{7}{|l|}{ HLA Match } \\
\hline Identical & 2 & 1 & 1 & 1 & 0 & 3 \\
\hline$\geq 1 \mathrm{H}$ & 30 & 13 & 13 & 6 & 3 & 16 \\
\hline$<1 \mathrm{H}$ & 8 & 3 & 3 & 0 & 2 & 3 \\
\hline $\begin{array}{l}\text { Ischaemia Time in } \\
\text { min.(mean } \pm \text { SD) }\end{array}$ & $141 \pm 42$ & $144 \pm 33$ & $158 \pm 37$ & $126 \pm 22$ & $144 \pm 33$ & $146 \pm 57$ \\
\hline $\begin{array}{l}\text { Best Creatinine } \mathrm{mg} / \mathrm{dl} \\
(\text { mean } \pm \mathrm{SD}) \\
\text { Maintenance } \\
\text { Immunosuppression }\end{array}$ & $1.3 \pm 0.23$ & $1.3 \pm 0.29$ & $0.9 \pm 0.34$ & $1.3 \pm 0.41$ & $1.3 \pm 0.12$ & $1.2 \pm 0.23$ \\
\hline CyA, Aza, Pred & 26 & 12 & 13 & 5 & 3 & 17 \\
\hline Tac, MMF, Pred & 7 & 3 & 3 & 0 & 1 & 3 \\
\hline CyA, MMF, Pred & 6 & 2 & 1 & 2 & 1 & 2 \\
\hline Tac, Aza, Pred & 1 & 0 & 0 & 0 & 0 & 0 \\
\hline \multicolumn{7}{|l|}{ eGFR $($ mean \pm SD) } \\
\hline At 1 month & $45 \pm 11$ & $41 \pm 9$ & $51 \pm 15$ & $44 \pm 11$ & $41 \pm 11$ & $51 \pm 12$ \\
\hline At 3 months & $47 \pm 11$ & $38 \pm 13$ & $48 \pm 18$ & $37 \pm 6$ & $32 \pm 8$ & $47 \pm 12$ \\
\hline At 6 months & $46 \pm 12$ & $41 \pm 11$ & $46 \pm 19$ & $39 \pm 13$ & $38 \pm 11$ & $52 \pm 10$ \\
\hline $\begin{array}{l}\text { Time of biopsy after } \\
\text { Tx in days (mean } \pm \text { SD) }\end{array}$ & $31 \pm 71$ & $37 \pm 42$ & $509 \pm 708$ & $16 \pm 25$ & $45 \pm 40$ & $41 \pm 33$ \\
\hline
\end{tabular}

$1 \mathrm{H}=$ one haplotype, $\mathrm{CyA}=$ cyclosporin, $\mathrm{Tac}=$ tacogen, Aza = azathiaprine, $\mathrm{MMF}=$ mycophenolate mofetil, Pred = prednisolone, Tx = transplant; eGFR $($ for male) $\{1.23(140$-age $) \mathrm{xwt}(\mathrm{kg}) / \mathrm{s} . \mathrm{cr}\} / 100$, for female $\{1.04(140$-age $) \mathrm{xwt}(\mathrm{kg}) / \mathrm{s.cr}\} / 100$.

Table 3. Comparison of mRNA levels in different biopsy groups with those classified as "Normal".

\begin{tabular}{|c|c|c|c|c|c|}
\hline \multirow{2}{*}{ GENE } & \multicolumn{5}{|c|}{ p-values $^{\text {b }}$} \\
\hline & $\operatorname{ACR}^{c}(N=40)$ & Infection $(N=17)$ & $\operatorname{CAN}^{\mathrm{d}}(\mathbf{N}=17)$ & $\operatorname{AVR}^{\mathbf{e}}(\mathbf{N}=7)$ & Borderline $(\mathrm{N}=5)$ \\
\hline GB & 0.000 & 0.087 & 0.325 & 0.001 & 0.606 \\
\hline Perforin & 0.000 & 0.279 & 0.240 & 0.002 & 0.650 \\
\hline FoxP3 & 0.000 & 0.305 & 0.904 & 0.070 & 0.447 \\
\hline TGF- $\beta$ & 0.000 & 0.039 & 0.492 & 0.006 & 0.928 \\
\hline $\mathrm{CD} 3 \varepsilon$ & 0.000 & 0.747 & 0.600 & 0.088 & 0.524 \\
\hline PI9 & 0.527 & 0.747 & 0.002 & 0.217 & 0.099 \\
\hline $\mathrm{TNF} \alpha$ & 0.193 & 0.457 & 0.229 & 0.258 & 0.377 \\
\hline IL-10 & 0.056 & 0.408 & 0.209 & 0.258 & 0.186 \\
\hline CTLA4 & 0.000 & 0.255 & 0.476 & 0.021 & 0.976 \\
\hline CXCR3 & 0.001 & 0.604 & 0.677 & 0.001 & 0.928 \\
\hline T-bet & 0.012 & 0.834 & 0.459 & 0.122 & 0.928 \\
\hline
\end{tabular}

${ }^{\mathrm{a}} 22$ classified as normal biopsy findings (mild non specific changes); ${ }^{\mathrm{b}} \mathrm{P}$-values based on Fishers Exact Sig. [2*(1-tailed Sig.)]; ${ }^{\mathrm{c}} \mathrm{ACR}$; Acute Cellular Rejection (IA,IB); ${ }^{\mathrm{d} C A N}$; Chronic Allograft Nephropathy; ${ }^{\mathrm{e}} \mathrm{AVR}$; Acute Vascular Rejection (IIA,IIB,III). 


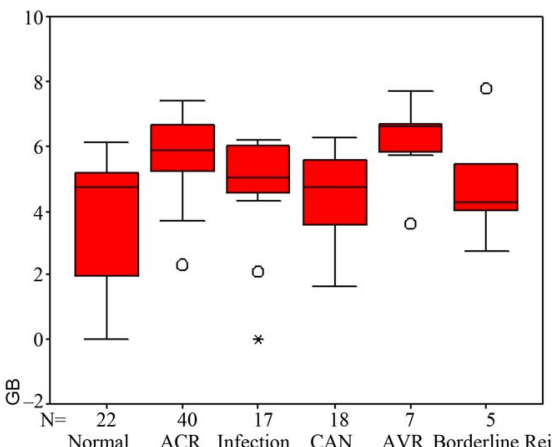

Normal ACR Infection CAN AVR Borderline Rej
GROUP

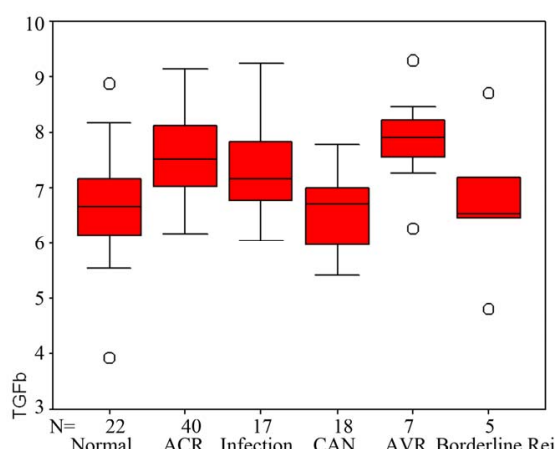

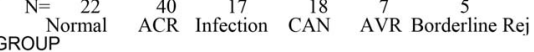

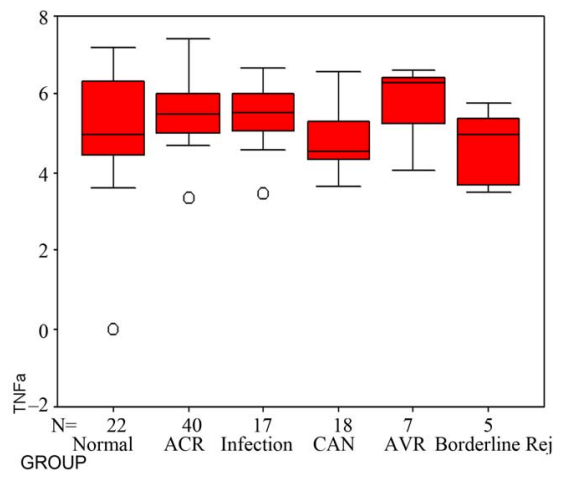

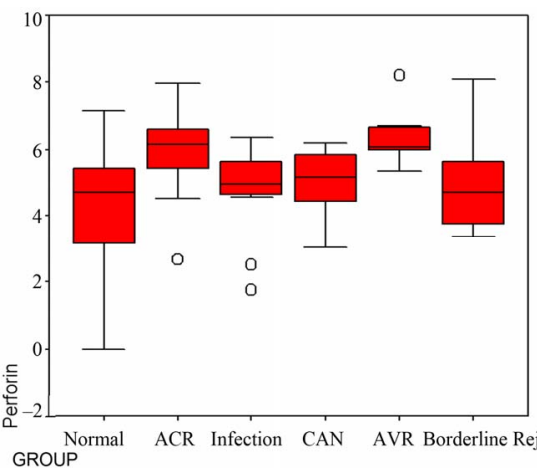
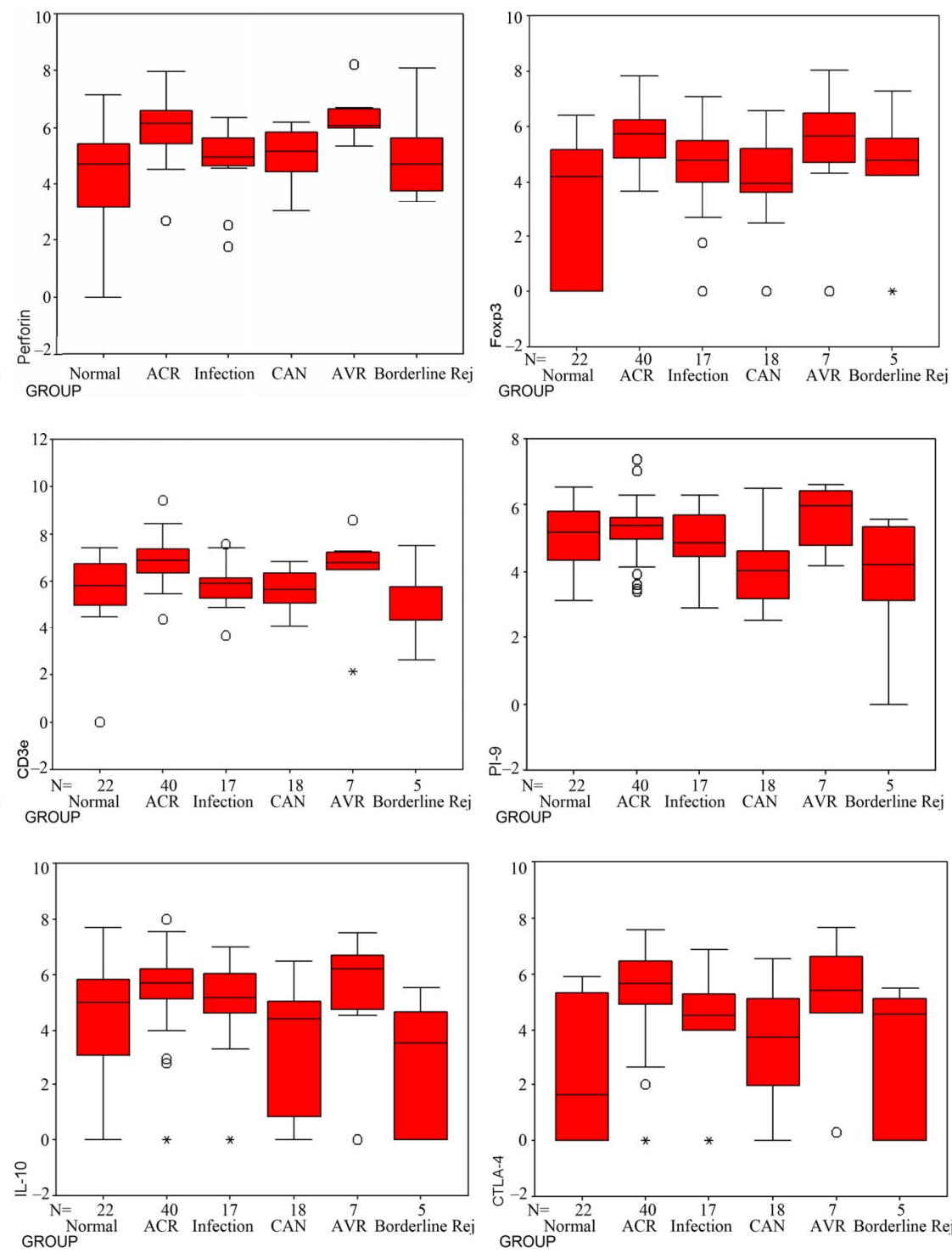

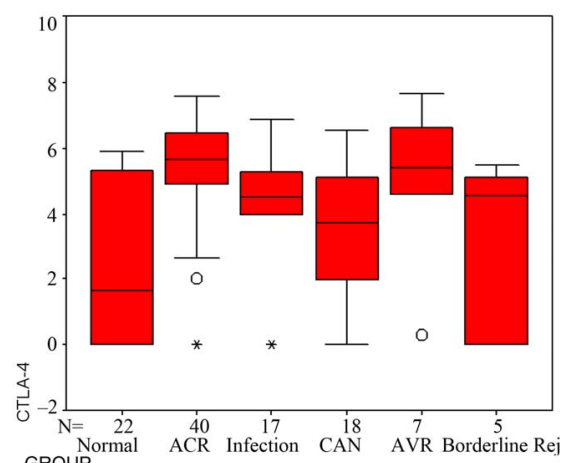
GROUP
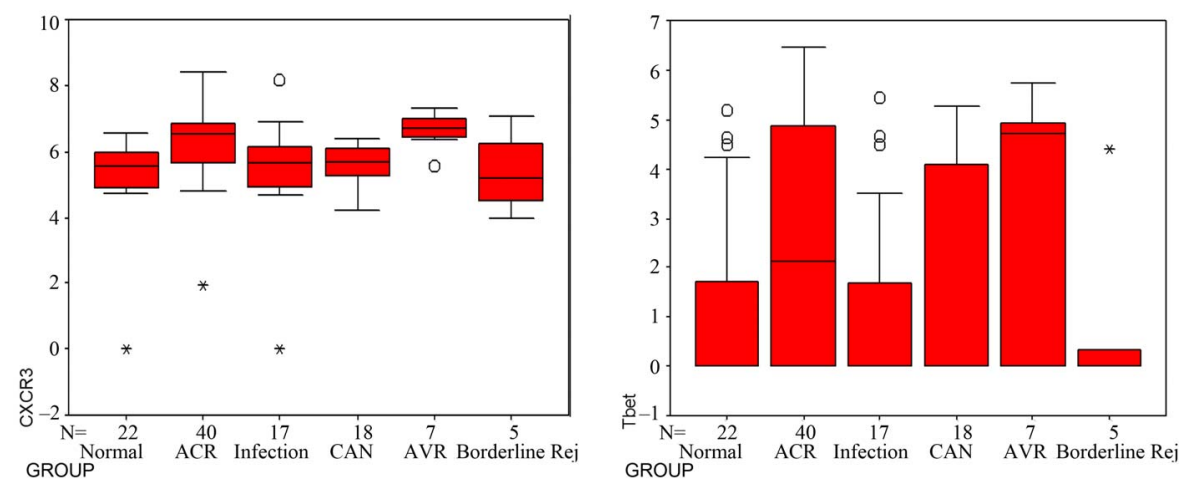

Box and whiskers plots show the 10th, 25th, 50th (median), 75th, and 90th percentile values for GB, Perforin, FoxP3, TGF- $\beta$, CD3 $\varepsilon$, PI9, TNF $\alpha$, IL-10, CTLA4,CXCR3 and Tbet in urine samples from 40 ACR, 17 CAN, 17 bacterial infection, 7 AVR, 5 border line rejection and 22 patients with normal biopsy results. Levels of mRNA for GB, Perforin, FoxP3, TGF- $\beta$, CD3 $\varepsilon$, CTLA4, CXCR3, and T-bet were higher in ACR than in patients with normal biopsy findings. GB, Perforin, TGF- $\beta$, CTLA4, and CXCR3 mRNA levels were also high in AVR. TGF- $\beta$ expression was also higher in infection, while PI9 levels were higher in CAN. P-values are based on the Mann-Whitney test, with the log-transformed mRNA levels treated as the dependent variable. Outliers are marked as 0 on plots. Asterisks represent extremes.ACR: We observed significant hyper expression of GB, perforin, FoxP3, TGF- $\beta$, CD3 $\varepsilon$, IL-10, CTLA4, CXCR3 and T-bet in this group.

Figure 1. Relative expression of mRNA transcripts in urinary cells after transplantation. 
expression of PI-9 was observed in this group while stable mRNA levels were detected for other genes.

Infection: This patient group showed significant hyper expression of TGF- $\beta(P=0.039)$ while rest were not significant.

\subsection{Receiver Operating Characteristic (ROC) Curve Analysis}

The ROC curve shows the fraction of true positive results (sensitivity) and false positive results (1-specificity) for cut off values of log transformed mRNA copy numbers. Perforin showed $97.5 \%$ sensitivity and $92.8 \%$ 1 -specificity at a cut off value of 2.87. GB, Foxp3, TGF- $\beta$, CD3 $\varepsilon, \mathrm{PI}-9$, CTLA4, and CXCR3 also showed sensitivity of $97.5 \%$, but with specificity varying from $87 \%, 71 \%, 76.8 \%, 91.3 \%, 87 \%, 68.1 \%$, and $94.2 \%$ respectively.

All these genes except PI-9 exhibited significant increase in gene expression in comparison to "mild nonspecific biopsy findings group" Table 3. The IL-10 showed $95 \%$ sensitivity and $79.7 \%$ specificity at a cut off value of 2.76 , while a cut off value of 1.07 for T-bet showed only $60 \%$ sensitivity and $36.2 \%$ specificity. The
TNF- $\alpha$ showed $97.5 \%$ sensitivity and $98.6 \%$ specificity at a cut off value of 3.42 , though it has a p-value of 0.193 when compared with "mild nonspecific biopsy findings" group Table 3 and Figure 2.

\subsection{Comparison of Treatment Response vs. No-Response in ACR}

Within the ACR group we compared those who showed complete response to anti rejection therapy (26 out of 40) with those who showed no response (8 out of 40), (remaining six patients fell in category of partial response). Using the Mann-Whitney test, we found insignificant values for all genes in terms of prediction of treatment response. (GB $\mathrm{p}=0.869$, perforin $\mathrm{p}=0.796$, FoxP3 $\mathrm{p}=0.760$, TGF $-\beta \mathrm{p}=0.944$, CD $3 \varepsilon \mathrm{p}=0.832$, PI-9 $\mathrm{p}=0.356$, TNF- $\alpha \mathrm{p}=0.655, \mathrm{IL}-10 \mathrm{p}=0.381$, CTLA4 $\mathrm{p}=$ 0.494, CXCR3 $\mathrm{p}=0.832$ and T-bet $\mathrm{p}=0.464$ )

\section{DISCUSSION}

The results of present study clearly demonstrate significantly increased expression of several cytokines and chemokine genes in patients with biopsy findings of acute rejection (AR). Urine samples in patients with ACR
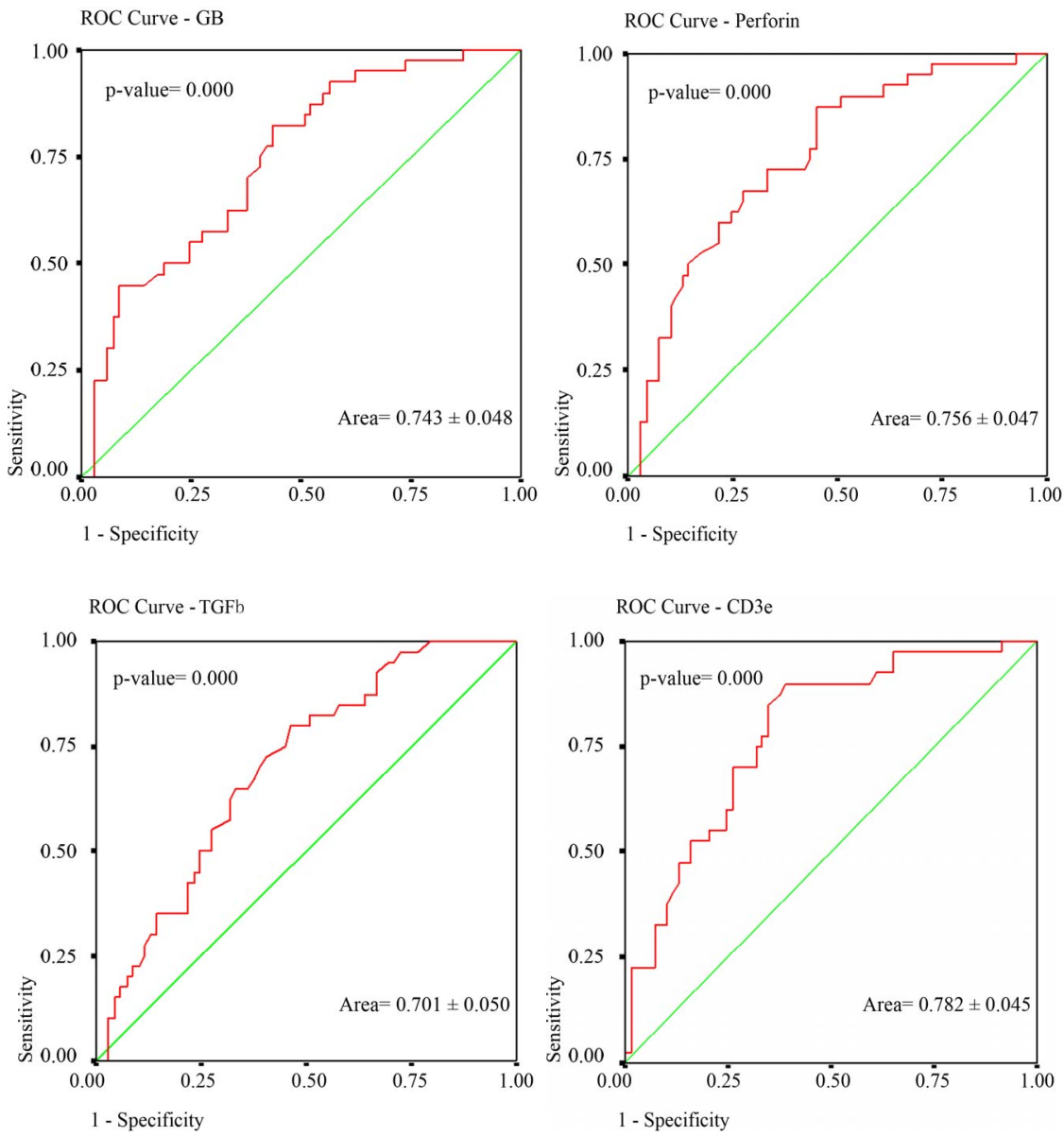
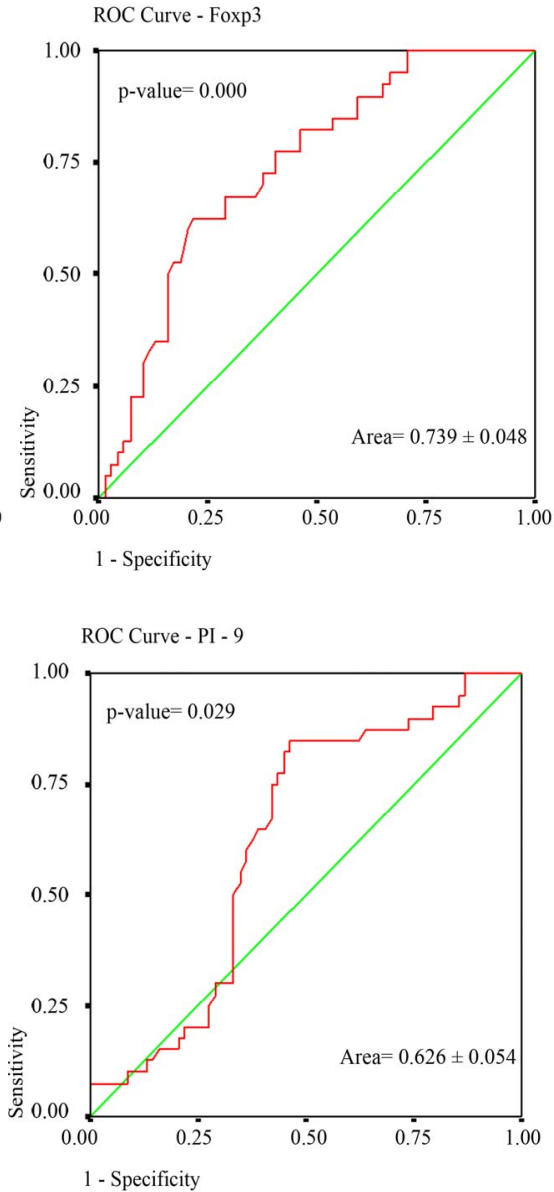

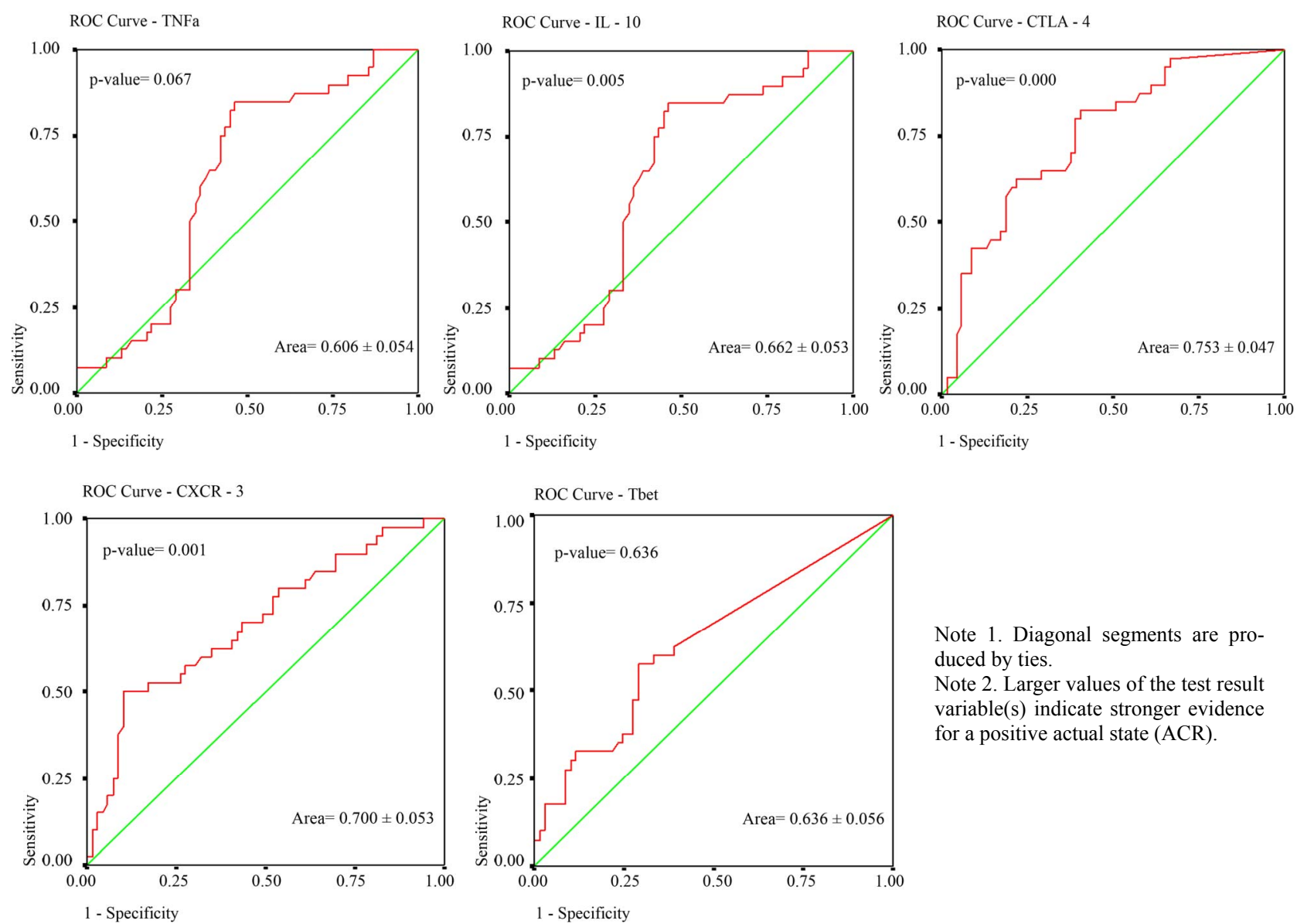

Note 1. Diagonal segments are produced by ties.

Note 2. Larger values of the test result variable(s) indicate stronger evidence for a positive actual state (ACR).

The fraction of true positive results (sensitivity) and false positive results (1-specificity) for levels of mRNA for GB, Perforin, FoxP3, TGF- $\beta$, CD3 $\varepsilon$, PI-9, TNF $\alpha$, IL-10, CTLA4,CXCR3 and T-bet as markers of ACR are shown. The calculated area under the curve is mentioned on the right corner. A value of 0.5 is no better than that expected by chance (the null hypothesis), and a value of 1.0 reflects a perfect indicator. P-values are indicated on left upper corner.

Figure 2. Receiver-Operating Characteristic (ROC) Curves of mRNA Levels in Acute Cellular Rejection (ACR).

displayed strong expression of GB, Perforin, TGF- $\beta$, FoxP3, CXCR3, CD3, T-bet and CTLA4. Cy- totoxic $\mathrm{T}$ Lymphocytes (CTLs) protein activation re- ported previously showed significant hyper-expression of GB and perforin in the setting of AR [9]. Another study which investigated association between enhanced urinary gene expression and early AR, reported high urinary CD3 and CTL granule associated molecule, granulysin. Effector cytokines and cytotoxic molecules (IL-2, IFN $\gamma$, IL-10, TNF- $\alpha$, TGF- $\beta$, RANTES, GB, per- forin and CCR1) were only marginally increased but were still found within the upper range of $95 \%$ confi- dence interval. Although researchers were able to predict AR with many fold enhancement of CD3 and granulysin mRNA expression, which was later proved on biopsy, yet serial mRNA amplification for gene expression analysis was found to be expensive and time consum- ing [11]. Another study also reported hyperexpression of GB, perforin and Fas-Ligand in biopsy samples as well as in peripheral blood leukocytes, though in the later samples, there was no statistically significant difference [10]. We have not analyzed the genes in biopsy samples or peripheral blood as our aim was to investigate non invasive markers for detecting the cause of graft dys- function.

FoxP3 gene expression is recognized as a predictive marker of AR. Muthu et al. reported high levels of FoxP3 mRNA in urinary cells as an independent predictor of reversal of $A R$, but the authorswere uncertain about the mechanisms of immunosuppression by Tregs, cytokines signaling and inhibition of transcription of genes central to effector functions in explanation of AR response [19]. The hyper-expression of FoxP3 has also been reported at the intra graft level in AR by using immunohistochemical method [21,34]. Mansour et al. reported intra graft FoxP3 mRNA levels as predictor of improved outcome in cases of borderline changes [36]. Elevated levels of FoxP3 in renal biopsy was also detected by Bunnag et al., but no association of mRNA levels with treatment response was seen [37]. In the present study we also found high levels of FoxP3 mRNA in ACR and AVR, but not in borderline rejection. We have also not found any significant difference in AR groups 
who completely responded to anti rejection therapy, versus those who had shown no response $(p=0.760)$. This variation in results could possibly be explained by the fact that FoxP3 binds promoters of over 700 genes and has both activating and inhibitory activity [38].

Chemokines are members of a large family of chemotactic cytokines, which play an important role in leukocyte recirculation. CXCR3, which is a marker for $\mathrm{T}$ helper cells type- 1 is associated with inflammatory process, its hyper-expression in renal allograft tissue has been reported in AR [16,17]. We have also seen hyper-expression of CXCR3 in cases of acute cellular or vascular rejection, whereas its hyper expression in cases of infection or CAN was insignificant (Table 3).

Considering role of CTLs in AR, PI-9 expression was also studied in setting of AR. As PI-9 can protect CTL from its self induced destruction and potentially enhances the strength of CTL, its correlation with AR and with subsequent graft function was studied. It was found that levels of PI-9 mRNA were higher in urinary cells from patients with AR compared with those without AR.[18] We found its levels slightly higher in cases of borderline rejection $(p=0.099)$, not significantly high in ACR $(p=0.527)$, but significantly high in cases of CAN $(p=0.002)$. To the best of our knowledge this is first such observation in patients with CAN, with an important implication, and needs to be further evaluated.

The generation of alloantigen specific CD25+ regulatory $\mathrm{T}$ cells was first studied in mice model by Kingsley et al. [14]. They demonstrated that blockade of both CTLA4 and IL-10 pathways abrogated the immune regulation of alloresponses mediated by $\mathrm{CD} 25+\mathrm{CD} 4+\mathrm{T}$ cells. Regulation of TGF- $\beta$ during T cell activation has been described to be effected with IL-10 [23,35]. Depending on the presence or absence of IL-10, which up-regulates TGF- $\beta$ expression, the primed T cells can either further differentiate into effector Th1 or Th2 cells or be negatively regulated by IL-10 and TGF- $\beta$ [23]. One isoform of TGF- $\beta$, TGF- $\beta 1$ not only enhances expression of integrins and decreases matrix degrading proteases, it also has immunosuppressive effect by I hibiting lymphocyte activation, and plays pro-inflammatory role in tissues. As a result of its various effects in different cell types it has been reported to be markedly upregulated in renal tissues from the graft in cases of AR, CAN and ATN $(p<0.001)$ and increased in borderline changes $(p<0.01)$, recurrence of glomerulonephritis and cyclosporin toxicity $(\mathrm{p}<0.05)$ [24]. This group did not report any correlation between intragraft TGF- $\beta 1$ expression during AR and short term outcome of a rejection episode. We have not studied its expression in ATN, recurrent glomerulonephritis or cyclosporin toxicity but demonstrated marked hyper expression in urine samples of patients with AR and bacterial urinary tract infection. (Table 3). This observation further helps in understanding the complex role of this gene in immune regulation of both normal and autoimmune states [39]. CTLA 4 expression is also up-regulated by T cell activation [32]. We have observed hyper-expression of CTLA 4 in cases of acute cellular as well as vascular rejections, whereas its expression was not significantly high in cases of borderline rejection, infection or CAN.

In response to different pathogen-derived antigens, CD4 $\mathrm{T}$ lymphocytes become either T helper $1\left(\mathrm{~T}_{\mathrm{H}} 1\right)$ or $\mathrm{T}$ helper $2\left(\mathrm{~T}_{\mathrm{H}} 2\right)$ cells depending on the type of pathogen. $\mathrm{T}_{\mathrm{H}} 1$ development is guided by its own transcription factor, T-bet, which positively regulates its own expression $[28,29]$. Earlier studies have demonstrated the hyperexpression of T-bet in the setting of AR [40]. The present study has also demonstrated significantly higher mRNA copy number of T-bet in AR cases, but its specificity is low (36.2\%) leaving its usefulness as non-invasive marker in dispute.

In summary, we have shown in this study that urinary cytokine/chemokine expression profile is a valuable technique in the accurate identification of the major causes of renal allograft dysfunction. Such non-invasive tests are highly desirable in a live related renal transplant program.

\section{ACKNOWLEDGEMENTS}

This work was initiated with inspiration of Dr. Suthanthiran's work, and after getting working experience of first author in his lab. We all are indebted to Dr. Suthanthiran's team, especially Dr. T.Muthukumar for providing continuous help with suggestions during the study, and Dr.R.Ding for helping in designing primers and probes for CTLA4 and T-bet.

\section{REFERENCES}

[1] Akhtar, F., Rana, T.A., Kazi, J., Zafar, N., Hashmi, A. Bhatti, S., et al. (1998) Correlation between Biopsies and Noninvasive Assessment of Acute Graft Dysfunction. Transplantation Proceeding, 30, 3069. doi:10.1016/S0041-1345(98)00933-6

[2] Gwinner, W. (2007) Renal transplant rejection markers. World Journal of Urology, 25, 445-455. doi:10.1007/s00345-007-0211-6

[3] Mannon, R.B. and Kirk, A.D. (2006) Beyond histology: Novel tools to diagnose allograft dysfunction. Clinical Journal of the American Society of Nephrology, 1, 358366.

[4] Yannaraki, M., Rebibou, J.M., Ducloux, D., Saas, P., Duperrier, A., Felix, S., et al. (2006) Urinary cytotoxic molecular markers for a noninvasive diagnosis in acute renal transplant rejection. Transplant International, 19, 759-768. doi:10.1111/j.1432-2277.2006.00351.x

[5] Strom, T.B. (2005) Rejection-more than the eye can see. 
New England Journal of Medicine, 353, 2394-2396. doi:10.1056/NEJMe058257

[6] Anglicheau, D. and Suthanthiran, M. (2008) Noninvasive prediction of organ graft rejection and outcome using gene expression patterns. Transplantation, 86, 192-199. doi:10.1097/TP.0b013e31817eef7b

[7] $\mathrm{Hu}, \mathrm{H}$. and Knechtle, S.J. (2006) Elevation of multiple cytokines/chemokines in urine of human renal transplant recipients with acute and chronic injuries: Potential usage for diagnosis and monitoring. Transplantation Review, 20, 165-171. doi:10.1016/j.trre.2006.07.003

[8] Suthanthiran M. (1998) Human renal allograft rejection: molecular characterization. Nephrology Dialysis Transplantation, 13, 21-24. doi:10.1093/ndt/13.suppl_1.21

[9] Li, B., Hartono, C., Ding, R., Sharma, V.K., Ramaswamy, R., Qian, B., et al. (2001) Noninvasive diagnosis of renal-allograft rejection by measurement of messenger RNA for perforin and granzyme B in urine. New England Journal of Medicine, 344, 947-954. doi:10.1056/NEJM200103293441301

[10] Graziotto, R., Del Prette, D., Rigotti, P., Anglani, F., Baldan, N., Furian, L., et al. (2006) Perforin, granzyme B, and fas ligand for molecular diagnosis of acute renal allograft rejection: Analyses on serial biopsies suggest methodological issues. Transplantation, 81, 1125-1132. doi:10.1097/01.tp.0000208573.16839.67

[11] Kotsch, K., Mashreghi, M.F., Bold, G., Tretow, P., Beyer, J., Matz, M., et al. (2004) Enhanced granulysin mRNA expression in urinary sediment in early and delayed acute renal allograft rejection. Transplantation, 77, 1866-1875. doi:10.1097/01.TP.0000131157.19937.3F

[12] Matz, M., Beyer, J., Wunsch, D., Mashreghi, M.F., Seiler, M., Pratschke, J., et al. (2006) Early post-transplant urinary IP-10 expression after kidney transplantation is predictive of short- and long-term graft function. Kidney International, 69, 1683-1690. doi:10.1038/sj.ki.5000343

[13] Kim, S.H., Oh, E.J., Ghee, J.Y., Song, H.K., Han, D.H., Yoon, H.E., et al. (2009) Clinical significance of monitoring circulating CD4+CD25+ regulatory T cells in kidney transplantation during the early posttransplant period. Journal of Korean Medical Science, 24, S135-142. doi:10.3346/jkms.2009.24.S1.S135

[14] Kingsley, C.I., Karim, M., Bushell, A.R., Wood, K.J. (2002) CD25+CD4+ regulatory $\mathrm{T}$ cells prevent graft rejection: CTLA-4- and IL-10-dependent immunoregulation of alloresponses. Journal of Immunology, 168, 10801086.

[15] Ding, R., Li, B., Muthukumar, T., Dadhania, D., Medeiros, M., Hartono, C., et al. (2003) CD103 mRNA levels in urinary cells predict acute rejection of renal allografts. Transplantation, 75, 1307-1312. doi:10.1097/01.TP.0000064210.92444.B5

[16] Tatapudi, R.R., Muthukumar, T., Dadhania, D., Ding, R., Li, B., Sharma, V.K., et al. (2004) Noninvasive detection of renal allograft inflammation by measurements of mRNA for IP-10 and CXCR3 in urine. Kidney International, 65, 2390-2397.

doi:10.1111/j.1523-1755.2004.00663.x

[17] Hoffmann, U., Segerer, S., Rümmele, P., Krüger, B., Pietrzyk, M., Hofstädter, F., et al. (2006) Expression of the chemokine receptor CXCR3 in human renal allografts - a prospective study. Nephrology Dialysis Transplantation,
21, 1373- 1381. doi:10.1093/ndt/gfk075

[18] Muthukumar, T., Ding, R., Dadhania, D., Medeiros, M., Li, B., Sharma, V.K., et al. (2003) Serine proteinase inhibitor-9, an endogenous blocker of granzyme B/perforin lytic pathway, is hyperexpressed during acute rejection of renal allografts. Transplantation, 75, 1565-1570. doi:10.1097/01.TP.0000058230.91518.2F

[19] Muthukumar, T., Dadhania, D., Ding, R., Snopkowski, C., Naqvi, R., Lee, J.B., et al. (2005) Messenger RNA for FOXP3 in the urine of renal-allograft recipients. New England Journal of Medicine, 353, 2342-2351. doi:10.1056/NEJMoa051907

[20] Wang, S., Jiang, J., Guan, Q., Lan, Z., Wang, H, Nguan, C.Y.C, et al. (2008) Reduction of Foxp3-expressing regulatory $\mathrm{T}$ cell infilterates during the progression of renal allograft rejection in a mouse model. Transplant Immunology, 19, 93-102. doi:10.1016/j.trim.2008.03.004

[21] Veronese, F., Rotman, S., Smith, R.N., Pelle, T.D., Farrell, M.L., Kawai, T., et al. (2007) Pathological and clinical correlates of FOXP3 + cells in renal allograft during acute rejection. American Journal of Transplantation, 7, 914922. doi:10.1111/j.1600-6143.2006.01704.x

[22] Navarro, J.F., Mora, C. and Muros, M. (2006) Urinary tumor necrosis factor- $\alpha$ excretion independently correlates with clinical markers of glomerular and tubulointerstitial injury in type 2 diabetic patients. Nephrology Dialysis Transplantation, 21, 3428-3434.

doi:10.1093/ndt/gfl469

[23] Cottrez, F. and Groux, H. (2001) Regulation of TGF-beta response during $\mathrm{T}$ cell activation is modulated by IL- 10 . Journal of Immunology, 167, 773-778.

[24] Pribylova-Hribova, P., Kotch, K., Lodererova, A., Vik icky, O., Vitko, S., Volk, H.D., et al. (2006) TGF- $\beta 1$ mRNA upregulation influences chronic renal allograft dysfunction. Kidney International, 69, 1872-1879. doi:10.1038/sj.ki.5000328

[25] Ibrahim, S., Saadi, G. and Al-Ansary, M. (2007) Estimation of serum and urinary profibrotic cytokines in renal allograft recipients. The Internet Journal of Nephrology, 4.

[26] Helantera, I., Teppo, A.M. and Koskinen, P. (2006) Increased urinary excretion of transforming growth factor $\beta 1$ in renal transplant recipients during cytomegalovirus infection. Transplant Immunology, 15, 217-221. doi:10.1016/j.trim.2005.11.001

[27] Pearce, E.L., Mullen, A.C., Martins, G.A., Krawczvk, C.M., Hutchins, A.S., Zediak, V.P., et al. (2003) Control of effector $\mathrm{CD} 8+\mathrm{T}$ cell function by the transcription factor Eomesodermin, Science, 302, 1041-1043. doi:10.1126/science. 1090148

[28] Szabo, S.J., Kim, S.T., Costa, G.L., Zhang, X., Fathman, C.G. and Glimcher, L.H. (2000) A Novel Transcription Factor, T-bet, detects Th1 Lineage Commitment, Cell, 100, 655-659. doi:10.1016/S0092-8674(00)80702-3

[29] Mullen, A.C., Hutchins, A.S., High, F.A., Lee, H.W., Sykes, K.J., Chodosh, L.A., et al. (2002) Hlx is induced by and genetically interacts with T-bet to promote heritable $\mathrm{T}(\mathrm{H}) 1$ gene induction. Nature Immunology, 3, 652 658.

[30] Callard, R.E. (2007) Decision making by the immune response. Immunology \& Cell Biology, 85, 300-305. doi:10.1038/sj.icb. 7100060 
[31] Linsley, P., Bradshaw, J., Greene, J., et al. (1996) Intracellular trafficking of CTLA-4 and focal localization towards sites of TCR engagement. Immunity, 4, 535-543. doi:10.1016/S1074-7613(00)80480-X

[32] Finn, P.W., He, H., Wang, Y., Wang, Z., Guan, G., Listman, J., et al. (1997) Synergistic induction of CTLA-4 expression by costimulation with TCR plus CD28 signals mediated by increased transcription and messenger ribonucleic acid stability. Journal of Immunology, 158, 40744081.

[33] Racusen, L.C., Solez, K., Colvin, R.B., et al. (1999) Banff 97 working classification of renal allograft pathology. Kid International, 55, 713-723. doi:10.1046/j.1523-1755.1999.00299.x

[34] Martin, L., Funes de la Vega, M., Bocrie, O., Harzallah, A., Justrabo, E., Rifle, G., et al. (2007) Detection of Foxp3+ cells on biopsies of kidney transplants with early acute rejection. Transplantation Proceedings, 39, 25862588. doi:10.1016/j.transproceed.2007.08.037

[35] Zeller, J.C., Panoskaltsis-Mortari, A., Murphy, W.J., Ruscetti, F.W., Narula, S., Roncarolo, M.G., et al. (1999) Induction of $\mathrm{CD}^{+} \mathrm{T}$ cell alloantigen-specific hyporesponsiveness by IL-10 and TGF- $\beta$. Journal of Immunology, 163, 3684 .
[36] Mansour, H., Homs, S., Desvaux, D., Badoul, C., Dahan, K., Matignon, M., et al. (2008) Intragraft levels of Foxp3 mRNA predict progression in renal transplants with borderline change. Journal of the American Society of $\mathrm{Ne}$ phrology, 19, 2277-2281. doi:10.1681/ASN.2008030254

[37] Bunnag, S., Allanach, K., Jhangri, G.S., Sis, B., Einecke, G., Mengel, M., et al. (2008) Foxp3 expression in human kidney transplant biopsies is associated with rejection and time post transplant but not with favorable outcome. American Journal of Transplantation, 8, 1423-11433. doi:10.1111/j.1600-6143.2008.02268.x

[38] Zheng, Y., Josefowicz, S.Z., Kas, A., Chu, T.T., Gavin, M.A. and Rudensky, A.Y. (2007) Genome wide analysis of Foxp3 target genes in developing and mature regulatory T cells. Nature, $\mathbf{4 4 5}, \mathbf{9 3 6}-940$. doi: $10.1038 /$ nature 05563

[39] Letterio, J.J. and Roberts, A.B. (1998) Regulation of Immune response by TGF $\beta$. Annual Review of Immunology, 16, 137. doi:10.1146/annurev.immunol.16.1.137

[40] Naqvi, R., Muthukumar, T., Dhadania, D., Ding, R., Snopkowski, C., Li, B. et al. (2005) The Yin and Yang of Allograft rejection: overexpression of T-bet as well as CTLA 4 during acute rejection of human renal allografts. Journal of the American Society of Nephrology, 34A. 